\title{
ADULTERATION IN MEDICINAL PLANTS AND HERBAL DRUGS
}

\author{
Raviraja Shetty G. and Harsha R. \\ Agricultural and Horticultural Research Station, Ullal, Mangalore \\ University of Agricultural \& Horticultural Sciences, Shivamogga, Karnataka, India
}

Received: 15.02.2021

Revised: 25.02.2021

Accepted: 10.03.2021

\begin{abstract}
Medicinal plants are considered as an effective source of traditional and modern medicine. In 20th and 21st century due to side effects of synthetic drugs, there is an increasing interest in Ayurvedic proprietary medicines. In India, about $80 \%$ of the rural population depends on medicinal herbs and/or indigenous system of medicine for primary health care. Adulterants and substitutes are the common malpractices in herbal raw material trade. Adulteration is considered as an intentional addition of foreign substances to increase the weight of the product or to decrease its cost. It may be due to Confusion in vernacular names, Lack of knowledge about authentic plants, Non availability, Similarity in morphology, activity, aroma, Careless collection and other unknown reasons. So, understanding of all the ways of adulteration and substitution is necessary to rectify this illegal act and maximizing consumer's safety.
\end{abstract}

Keywords: Medicinal plants, health, adverse effect, cultivation and adulteration.

\section{INTRODUCTION}

The adulteration and substitution of herbal drugs is the burning problem in herbal industry and it has caused a major effect in the commercial use of natural products. Populations of many species have limited distribution in their natural habitats, requiring conservation strategies for protection. Unavailability of such medicinal plants has led to arbitrary substitution and adulteration of raw drug in the market (Tewari et al., 1991 and Bisset et al., 1984). Adulteration more precisely defined as a practice of substituting original crude drug partially or whole with other similar looking substances which are either free from or inferior in chemical and therapeutic properties or addition of low grade or spoiled drugs or entirely different drug similar to that of original drug substituted with an intention of enhancement of profits (Kokate et al., 2007 and Mukherjee et al., 2002).

A adulteration may also be defined as mixing or substituting the original drug material with other spurious, inferior, defective, spoiled, useless other parts of same or different plant or harmful substances or drug which do not confirm with the official standards. A drug shall be deemed to be adulterated if it consists, in whole or in part, of any filthy, putrid or decomposed substance (The Drugs and Cosmetics Act., 1940 and The Drugs and Cosmetics Rule., 1945) Adulteration is described as intentional substitution with another plant species or intentional addition of a foreign substance to increase the weight or potency of the product or to decrease its cost. In general, adulteration is considered as an intentional practice. Due to adulteration, faith in herbal drugs has declined (Dubey et al., 2004). Adulteration in market samples is one of the greatest drawbacks in promotion of herbal products.

\section{ADULTERATION MAY TAKES PLACE BY TWO WAYS: \\ $>$ Direct or intentional adulteration \\ $>$ Indirect or unintentional adulteration \\ Direct or intentional adulteration \\ Direct or intentional adulteration is done intentionally which usually includes practices in which an herbal drug is substituted partially or fully with other inferior products.}

*Corresponding author: rrshetty2059@gmail.com 
Due to morphological resemblance to the authentic herb, many different inferior commercial varieties are used as adulterants. These may or may not have any chemical or therapeutic potential. Substitution by “exhausted” drugs entails adulteration of the plant material with the same plant material devoid of the active constituents. This practice is most common in the case of volatile oilcontaining materials, where the dried exhausted material resembles the original drug but is free of the essential oils. Foreign matter such as other parts of the same plant with no active ingredients, sand and stones, manufactured artefacts, and synthetic inferior principles are used as substitutes. The practice of intentional adulteration is mainly encouraged by traders who are reluctant to pay premium prices for herbs of superior quality, and hence are inclined to purchase only the cheaper products. This encourages producers and traders to sell herbs of inferior quality. (Jaya Preethi et al., 2014)

\section{Indirect or unintentional adulteration}

Unintentional or undeliberately adulteration which sometimes occurs without bad intention of the manufacturer or supplier. Sometimes in the absence of proper means of evaluation, an authentic drug partially or fully devoid of the active ingredients may enter the market. Factors such as geographical sources, growing conditions, processing, and storage are all factors that influence the quality of the drug (Poornima et al., 2010).

\section{Faulty collection}

Some of the herbal adulteration is due to the carelessness of herbal collectors and suppliers. The correct part of genuine plant should be collected. Other less valuable part of the genuine plant should not be collected. Moreover collection should be carried out at a proper season and time when the active constituents reach maximum. Datura strumarium leaves should be collected during flowering stage and wild cherry bark in autumn etc. collection from other plant by ignorance, due to similarity in the appearance, color, lack of knowledge may lead to adulteration. For example in place of Aconitum napellus, the other Aconitum deinorhizum may be collected or in place of Rhamnus purshiana (cascara bark) Rhamnus colifornica is generally collected. Confusion existing in the common vernacular name of different plant in various states of india may leads to this type of adulteration. Often in different states the same plant is known by different vernacular names, while quite different drugs are known by same name. This creates confusion which is best illustrated by Punarnava and Brahmi. The Indian pharmacopoeia drugs Trianthema portulacastrum L. and Boerhavia diffusa L. are both known by the same vernacular name "Punarnava” (Jaya Preethi et al., 2014).

\section{Imperfect preparation}

Non removal of associated structures e.g. stems are collected with leaves, flowers, fruits. Non-removal of undesirable parts or structures e.g. cork should be removed from ginger rhizome. Proper drying conditions should be adhered. Improper drying may lead to unintentional adulteration e.g. if digitalis leaves are dried above 65oc decomposition of glycosides by enzymatic hydrolysis. Use of excessive heat in separating the code liver oil from livers, where the proportions of vitamins, odour and color etc are adversely affected (Jaya Preethi et al., 2014).

\section{Incorrect storage}

Deterioration especially during storage, leading to the loss of the active ingredients, production of metabolites with no activity and, in extreme cases, the production of toxic metabolites. Physical factors such as air (oxygen), humidity, light, and temperature can bring about deterioration directly or indirectly. These factors, alone or in combination, can lead to the development of organisms such as molds, mites, and bacteria. Oxidation of the constituents of a drug can be brought about by oxygen in the air, causing some products, such as essential oils, to resinify or to become rancid. Moisture or humidity and elevated temperatures can accelerate enzymatic activities, leading to changes in the physical appearance and decomposition of the herb. For example volatile oils should be protected from light and stored in well closed containers in cool place. Belladonna leaf should be stored in moisture free containers, which may cause enzymatic action lead to decomposition of medicinally active constituents. Mites, nematode worms, insects/moths, and beetles can also destroy herbal drugs during storage (Jaya Preethi et al., 2014).

\section{Gross substitution with plant material}

Due to morphological resemblance i.e. similarity in appearance, colors etc the genuine crude drugs are substituted with others are very often sold in the market e.g. Podophyllum peltatum L. is used as a substitute for $P$. hexandrum, Belladona leaves are substituted with Ailanthus leaves.

\section{Substitution with exhausted drugs}

In this type, the same drug is admixed but devoid of any medicinally active constituents as they are already extracted out. This practice is more common in case of volatile oil containing drugs sometime, natural characters of exhausted drugs like color and taste are manipulated by adding other additives and then it is substituted e.g. exhausted gentian made bitter with aloes.

\section{Reasons for adulteration}

\section{Confusion in Vernacular Names:}

In Ayurveda, Parpatta refers to Fumaria parviflora. In Siddha, 'Parpadagam' refers to Mollugo pentaphylla. Owing to the similarity in the names in traditional systems 
of medicine, these two herbs are often interchanged or adulterated or substituted. Because of the popularity of Siddha medicine in some parts of South India, traders in these regions supply Mollugo pentaphylla as Parpatta/Parpadagam and the North Indian suppliers supply F. parviflora. These two can be easily identified by the presence of pale yellow to mild brown colored, thin wiry stems and small simple leaves of Mollugo pentaphylla and black to dark brown colored, digitate leaves with narrow segments of F. parviflora. Casuarina equisetifolia for Tamarix indica and Aerva lanata for Berginiaciliate are some other example for adulterations due to confusion in names (Sarin et al., 1996).

\section{Lack of Knowledge About Authentic Source}

Nagakesar is one of the important drugs in Ayurveda. The authentic source is Mesua ferrea. However, market samples are adulterated with flowers of Calophyllum inophyllum. Though the authentic plant is available in plenty throughout the Western Ghats and parts of Himalayas, suppliers are unaware of it. There may also be some restrictions in forest collection. Due to these reasons, C. inophyllum (which is in the plains) is sold as Nagakesar. Authentic flowers can be easily identified by the presence of two-celled ovary whereas in case of spurious flowers they are single celled (Sarin et al., 1996).

\section{Similarity in Morphology}

Mucuna pruriens is adulterated with other similar Papilionaceae seeds having similarity in morphology. $M$. utilis (sold as white variety) and $M$. deeringiana (sold as bigger variety) are popular adulterants. Apart from this M.cochinchinensis, Canavalia virosa and C.ensiformis are also sold in Indian markets. Authentic seeds are up to $1 \mathrm{~cm}$ in length with shining mosaic pattern of black and brown color on their surface. $M$. deeringiana and $M$. utilis are bigger $(1.5-2 \mathrm{~cm})$ in size. While $M$. Deeringiana is dull black and M. utilis is white or buff colored(Sarin et al., 1996).

\section{Lack of Authentic Plant:}

Hypericum perforatum is cultivated and sold in European markets. In India, availability of this species is very limited. However, the abundant Indo-Nepal species $H$. patulum, sold in the name of $H$. perforatum. Market sample is a whole plant with flowers and it is easy to identify them taxonomically. Anatomically, transverse section of $H$. perforatum stem has compressed thin phloem, hollow pith and absence of calcium oxalate crystals. Whereas $H$. patulum hasbroader phloem, partially hollow pith and presence of calcium oxalate crystals

(Pawan Kumar et al., 2014).

\section{Similarity in Color}

It is well known that with course of time, drug materials get changed to or substituted with other plant species. 'Ratanjot' is a recent day example. According to the suppliers and non-timer forest product (NTFP) contractors, in the past, roots of Ventilago madraspatana were collected from Western Ghats, as the only source of 'Ratanjot'. However, that has not been practiced now. It is clearly known that Arnebia euchromavareuchroma is the present source. Similarity is in yielding a red dye, A. euchroma substitutes V.madraspatana. Recently V. madraspatana is not found in market. Whatever is available in the market, in the name of Ratanjot is originated from A. Euchroma (Mitra et al., 2007 and Chouhan et al., 1999).

\section{Careless Collections}

Some of the herbal adulterations are due to the carelessness of herbal collectors and suppliers. Parmelia perlata is used in Ayurveda, Unani and Siddha. It is also used as grocery. Market samples showed it to be admixed with other species (P.perforata and P. cirrhata). Sometimes, Usnea sp. is also mixed with them. Authentic plants can be identified by their thallus nature (Poornima et al.,2010 and Roy et al., 2013).

\section{ADULTERATED OR SUBSTITUTE PARTS USED IN MEDICINAL PLANTS}

\begin{tabular}{|l|l|l|l|l|}
\hline Sl. No & $\begin{array}{l}\text { Original and costly } \\
\text { Raw Drugs }\end{array}$ & Botanical name & $\begin{array}{l}\text { Adulterated/Substitute } \\
\text { drug }\end{array}$ & Botanical name \\
\hline 1. & Tulasi & Ocimum sanctum & Nirgundi & Vitex negundo \\
\hline 2. & Asoca & Saraca asoca & False ashoka & Polyanthia longifolia \\
\hline 3. & Indian senna & Cassia angustifolia & Dog senna & Cassia abovata \\
\hline & & & Palthe senna & Cassia auriculatad \\
\cline { 3 - 5 } & Alexandrian senna & Cassia acutifolia & Dog senna & Cassia abovata \\
\cline { 3 - 5 } & & & Palthe senna & Cassia auriculatad \\
\hline 5 & Aloes & Aloe barbadensis & Natal aloes & Aloe barberae \\
\hline
\end{tabular}




\begin{tabular}{|c|c|c|c|c|}
\hline 6. & Digitalis & Digitalis purpurea & Primrose & Primula vulgaris \\
\hline 7. & Liquorice & Glycyrrhiza glabra & Russian Liquorice & Glycyrrhiza echinata \\
\hline 8. & Opium & Papaver somniferum & Turkish opium & \\
\hline 9. & Belladona & Atropa belladonna & Black nightshade & Solanum nigrum \\
\hline 10. & Bakula & Mimusops elengi & Kamala & Nelumbo nucifera \\
\hline \multirow[t]{2}{*}{11.} & \multirow[t]{2}{*}{ Puskar mool } & \multirow[t]{2}{*}{ Inula racemosa } & Eranda(root) & Ricinus communis \\
\hline & & & Kustha & Saussrea lappa \\
\hline 12 & Bharangi & Clerodendrum serratum & Kantakari & Solanum xanthocarpum \\
\hline 13 & Tagar & Valeriana wallichii & Kustha & Saussrea lappa \\
\hline 14 & Chavya & Piper chaba & Pippali (root) & Piper longum \\
\hline 15 & Draksha & Vitis vinifera & Kashmari phala & Gmelina arborea \\
\hline 16 & Chitrak & Plumbago zeylanica & Danti & $\begin{array}{l}\text { Baliospermum } \\
\text { montanum }\end{array}$ \\
\hline 17 & Dhanavayasa & Fagonia cretica & Duralabha & Alhagi pseudalhagi \\
\hline 18 & Ahimsa & Capparis sepiaria & Manakanda & Alocasia indica \\
\hline 19 & Bhallataka & Semecarpus anacardium & Nadi Bhallataka & $\begin{array}{l}\text { Semecarpus } \\
\text { Travancorica }\end{array}$ \\
\hline 20 & Murva & Marsdenia tenacissima & Jinghini & Lannea coromandelica \\
\hline 21 & Ikshu & Saccharum officinarum & Nala & Arundo donax \\
\hline 22 & Ativisha & Aconitum heterophyllum & Mustaka & Cyperus rotundus \\
\hline 23 & Riddhi and Vriddhi & Hobenaria spp. & Varahikanda & Dioscorea bulbifera \\
\hline 24 & Kakoli & Lilium polyphyllum & Asvagandha & Withania somnifera \\
\hline 25 & Kshirakakoli & Fritillaria roylei & Asvagandha & Withania somnifera \\
\hline 26 & Karpua & Cinnamomum Camphora & Granthi parna & Leonotis nepetafolia \\
\hline 27 & Dadim & Punica granatum & Vrikshamla & Garcinia indica \\
\hline 28 & Kusha & Desmostachya bipinnata & Kasha & Saccharum spontaneum \\
\hline 29 & Kutherika & Ocimum basilicum & Gramya tulasi & Ocimum sanctum \\
\hline 30 & Nagapuspa & Mesua ferrea & Padma kesar & Nelumbo nucifera \\
\hline 31 & Vatsnabh & Aconitum Chasmanthum & Mohri & Aconitum ferox wall \\
\hline 32 & Ativisha & Aconitum heterophyllum & Mustaka & Cyperus rotundus \\
\hline 33 & Kutki & $\begin{array}{l}\text { Picrorhiza kurroa } \\
\text { royle ex }\end{array}$ & Kuth or Kout & Saussurea castus \\
\hline 34 & Kuth or Kustha & Saussurea lappa & Kuth or Kout & Saussurea castus \\
\hline 35 & Puskar mool & Inula racemosa & Kustha & Saussrealappa \\
\hline 36 & Jatamansi & Nardostachys Jatamansi & Bhootkeshi & Selinum vaginatum \\
\hline \multirow[t]{2}{*}{37} & \multirow[t]{2}{*}{ Guggulu } & \multirow[t]{2}{*}{ Commiphora wightii } & Babul, Kikar & Acacia nilatica \\
\hline & & & $\begin{array}{l}\text { Myrrha gond or } \\
\text { myrrh gum }\end{array}$ & Commiphora myrrha \\
\hline 38 & Rumi Mastagi & Pistacia lentisecus Linn & $\begin{array}{l}\text { Salai guggul or } \\
\text { Gum olibanum }\end{array}$ & Frankincense indica \\
\hline
\end{tabular}




\begin{tabular}{|c|c|c|c|c|}
\hline 39 & Riddhi & Hobenaria intermedia & Varahikand & Dioscorea bulbifera \\
\hline & & & Chiriya Musali & Asparagus filicinus \\
\hline \multirow[t]{3}{*}{40} & \multirow[t]{3}{*}{ Vriddhi } & \multirow[t]{3}{*}{ Habenaria edgeworthii } & Varahikand & Dioscorea bulbifera \\
\hline & & & Salam Panja & Dactylorhiza hatagirea \\
\hline & & & Maha bala & Sida acuta Burm. f \\
\hline \multirow[t]{2}{*}{41} & \multirow[t]{2}{*}{ Kakoli } & \multirow[t]{2}{*}{ Roseea purpurrea Smith } & $\begin{array}{l}\text { Ashwagandha, } \\
\text { Asrol, Asgandh Nagori }\end{array}$ & $\begin{array}{l}\text { Withania somnifera } \\
\text { Dunal }\end{array}$ \\
\hline & & & Kali Musali & Corculigo orchioids \\
\hline \multirow[t]{2}{*}{42} & \multirow[t]{2}{*}{ Kshirakakoli } & \multirow[t]{2}{*}{ Fritillaria roylei Hook } & $\begin{array}{l}\text { Ashwagandha, Asrol, } \\
\text { Asgandh Nagori }\end{array}$ & $\begin{array}{l}\text { Withania somnifera } \\
\text { Dunal }\end{array}$ \\
\hline & & & Safed Musali & $\begin{array}{l}\text { Chlorophytum } \\
\text { arundinaceum }\end{array}$ \\
\hline \multirow[t]{3}{*}{43} & \multirow[t]{3}{*}{ Jeevak } & \multirow[t]{3}{*}{ Crepipium acuminatum } & Varahikand & Dioscorea bulbifera \\
\hline & & & Safed behman & Centaurea behen \\
\hline & & & Guruchi & Tinospera cordifolia \\
\hline \multirow[t]{2}{*}{44} & \multirow[t]{2}{*}{ Rishbhak } & \multirow[t]{2}{*}{ Malaxis muscifera } & Varahikand & Dioscorea bulbifera \\
\hline & & & Lal behmen & Centaurium roxburghi \\
\hline \multirow[t]{2}{*}{45} & \multirow[t]{2}{*}{ Meda } & \multirow[t]{2}{*}{$\begin{array}{l}\text { Polygonatum } \\
\text { verticillatum }\end{array}$} & Satavari & $\begin{array}{l}\text { Asparagus racemosus } \\
\text { willd }\end{array}$ \\
\hline & & & Salam mishri & Eulophia campestris wall \\
\hline \multirow[t]{3}{*}{46} & \multirow[t]{3}{*}{ Maha meda } & \multirow[t]{3}{*}{$\begin{array}{l}\text { Polygonatum } \\
\text { Vertecillatum }\end{array}$} & Satavari & $\begin{array}{l}\text { Asparagus racemosus } \\
\text { willd }\end{array}$ \\
\hline & & & Shakakul mishri & $\begin{array}{l}\text { Polygontatum } \\
\text { multiflorum }\end{array}$ \\
\hline & & & Prasarani & Paederia foetida Linn \\
\hline 47 & $\begin{array}{l}\text { Rakta Chandana or } \\
\text { Sandal Surkh }\end{array}$ & $\begin{array}{l}\text { Pterocarpus santalinus } \\
\text { Linn }\end{array}$ & $\begin{array}{l}\text { Red Capsicum, } \\
\text { Lal shimla mirch }\end{array}$ & $\begin{array}{l}\text { Capsicum annuum Linn., } \\
\text { Capsicum baccatum } \\
\text { Linn. and Capsicum } \\
\text { frutescens Linn }\end{array}$ \\
\hline 48 & $\begin{array}{l}\text { Sveta Chandana or } \\
\text { Sandal Safed }\end{array}$ & $\begin{array}{l}\text { Pterocarpus santalinus } \\
\text { Linn }\end{array}$ & $\begin{array}{l}\text { White Capsicum, } \\
\text { Safed shimla mirch }\end{array}$ & Capsicum annuum Linn \\
\hline
\end{tabular}

\section{Remedies of adulteration}

- Cultivation of medicinal plants

- Judicious collection of medicinal plants from wild

- Right collection at right time

- Identification/Authentication

- Building up a Herbarium \& Museum

\section{CONCLUSION}

Adulteration of medicinal plants is not only intentional malpractice as stated in many literatures. With experience it is noted that the herbal drugs are adulterated unintentionally also. Major causes for adulteration are confusion in vernacular names, Non availability, Lack of knowledge about authentic plants, Similarity in morphology, activity, aroma, Careless collection and other unknown reasons. Suppliers are illiterate and not aware about their spurious supply Even scientific community and traditional physicians are unaware of it. Nowadays, Ayurvedic drug industries follow high quality standards using modern techniques and instruments to maintain their quality. World Health Organization (WHO), in its publication on quality standards for medicinal plant materials, recommends rejecting any batch of raw material, which has more than $5 \%$ of any other plant part of the same 
plant (e.g. stem in leaf drugs), never the less if they are derived from the authentic plant. Based on these standards, adulteration whether, intentional or unintentional, should be rejected. Also, suppliers and traders should be educated about the authentic sources. After understanding the ways of adulteration, more research and information required to rectify and minimize the illegal act adulteration, for improving consumers' safety. For this purpose we can take help from scientific literature, expert opinion, pharmacology, kinetics/dynamics, interactions, adverse effects, toxicology and dosing.

\section{REFERENCES}

1. Kokate, C. K., Purohit, A. Pand Gokhele, S. B. (2007). Pharmacognosy. Chapter-6, Edn 39, Nirali Prakashan, Pune, 97-98.

2. Mukherjee, P.K. (2002) Quality Control of Herbal drugs. Edn 1, Business Horizons, New Delhi, 113-117.

3. Anonymous, The Drugs and Cosmetics Act and Rule, The Drugs and Cosmetics Act 1940, The Drugs and Cosmetics Rule 1945, Government of India, Ministry of Health and Family Welfare, chapter 2, 2003, 5.

4. Dubey, N.K., Kumar,R. and Tripathi, P. (2004) Global promotion of herbal medicine: India's opportunity. Current Science. 86(1):37-41.

5. Tewari, N. N. (1991) Some crude drugs: source, substitute and adulterant with special reference to KTM crude drug market. Sachitra Ayurved. 44(4): 284-290.

6. Bisset, W. G. (1984) Herbal drugs \& phytopharmaceuticals, CRC Press, London.

7. Jaya Preethi, P., Padmini, K., Lohita, M., Swetha, K., Priyanka, B. and Vengal Rao, P. (2014). Adulterants and substitutes of foods and herbs: a review. International Journal of Medicinal Chemistry \& Analysis. 4(4): 213-217.

8. Poornima, B. (2010) Adulteration and Substitution in Herbal Drugs a Critical Anaysis. International
Journal of Research in Ayurveda \& Pharmacy. 1(1) 812.

9. Simple tests for common adulterants in food.www.angelfire.com/co4/dhimanbiswas/adulter ation.htm.

10. Anonymous. http://www.chennaicorporation.gov.in /departments/health/adulteration.htm.

11. A nonymous.http: / / d o c tor.ndtv.com / storypage/ndtv/id/3731/type/feature/Food_adulterati onhtml.

12. Sarin,Y. K. (1996) Illustrated Manual of Herbal drugs used in Ayurveda, Joint Publication of C.S.I.R and I.C.M.R, New Delhi.

13. Mitra, S. K. and Kannan R. (2007) A Note on Unintentional Adulterations in Ayurvedic Herbs. Ethno botanical Leaflets. 11: 11-15.

14. Roy Anirban Mallick Arindam Kaour Amrinder (2013). Adulteration and substitution in Indian medicinal plants, (ISSN: 2277-8713); IJPRBS. 2(1): 208-218.

15. Shah, B. and Seth, A.K. (2010) Test book of pharmacognosy \& phytochemistry ; Drug Adulteration Chapter 10: 107-109.

16. Sunita G. (1992) Substitute and adulterant plants, Periodical Experts Book Agency, New Delhi.

17. Uniyal, M. R. and Joshi, G. C. (1993). Historical view of the basic principles of the identification of controversial drugs, problems and suggestions. Sachitra Ayurved; 45(7):531-536.

18. Saraswathy A. Adulterants and substitutes in Ayurveda. Sachitra Ayurved. 2001; 54(1):63-66.

19. De,S. PAGM., Keller,K., Hansel,R. and Chandler, R.F. (1992)Adverse effects of herbal drugs. Vol. 1. Springer Verlag, Heidelberg.

20. Gupta, A.K. (2003) Quality standards of Indian medicinal plants, Vol. I. ICMR, New Delhi. 